NONA GORGONIA PABA, WAHYUNINGSI, ERWIN PRASETYO, MUHAMAD EPI RUSDIN

Analisis Hasil Belajar Matematika Siswa Di SMK Negeri 1 Maumere

\title{
Analisis Hasil Belajar Matematika Siswa Di SMK Negeri 1 Maumere
}

\author{
Nona Gorgonia paba ${ }^{1}$, Wahyuningsi ${ }^{2}$, Erwin Prasetyo ${ }^{3}$, Muhamad Epi Rusdin ${ }^{4}$ \\ 1,2,3Program Studi Pendidikan Matematika, IKIP Muhammadiyah Maumere \\ ${ }^{4}$ Program Studi Pendidikan Fisika, IKIP Muhammadiyah Maumere \\ *nonagorgoniapaba@gmail.com
}

\begin{abstract}
ABSTRAK
Hasil belajar siswa merupakan suatu tolak ukur keberhasilan siswa dalam proses pembelajaran di kelas, penelitian ini bertujuan untuk mengetahui kualitas hasil belajar siswa dan aspek yang mempengaruhi hasil belajar matematika pada perbandingan trigonometri pada segitiga siku-siku berdasarkan rana kognitif di SMK Negeri 1 Maumere. jenis penelitian kualitatif dengan metode deskriptif kualitatif, Subjek penelitian adalah siswa kelas X DPIB-2 dengan jumlah 34 orang. Penelitian ini menggunakan Teknik pengumpulan data dengan pemberian soal tes dan wawancara. Teknik analisis yang digunakan dalam penelitian ini adalah Teknik analisis data deskriptif kualitatif meliputi data reduction, data display, dan verification. Hasil penelitian ini menunjukan bahwa hasil belajar pada siswa kriteria Rendah dengan jumlah cukup, kriteria sedang jumlahnya sangat banyak, kriteria tinggi jumlahnya banyak, kriteria sangat tinggi jumlahnya kurang. Sedangkan aspek mempengaruhi hasil belajar siswa adalah aspek internal dan aspek eksternal, aspek internal meliputi minat belajar siswa kurang, kemampuan pemahaman siswa kurang, daya ingat siswa dan keahlian berhitung siswa kurang, sedangkan aspek eksternal meliputi perhatian dan dukungan keluarga terhadap siswa untuk mengulangi materi diberikan oleh guru di rumah.
\end{abstract}

Kata kunci: Analisis, Hasi Belajar, Pembelajaran Matematika.

\begin{abstract}
Student learning outcomes are a measure of student success in the learning process in class, and this study aims to determine the quality of student learning outcomes and aspects that affect mathematics learning outcomes in the comparison of trigonometry in a right triangle based on cognitive shutter at SMK Negeri 1 Maumere. Type of qualitative research with qualitative descriptive methods. Research subjects were students of class X DPIB-2 with a total of 34 people. This study uses data collection techniques by giving test questions and interviews. The analysis technique used in this research is descriptive qualitative data reduction, data display, and verification. The results of this study indicate that the learning outcomes of students with a low criterion are sufficient, the criteria are very large in number, the criteria for high are many, very high criteria the number is lacking. While the aspects affecting student learning outcomes are internal aspects and external aspects, internal aspects include students lack of interest in learning, students lack of understanding, memory and numeracy skills, while the external aspect includes family attention and support for students to repeat the material given by the teacher at home.
\end{abstract}

Key words: Analysis, Learning Outcomes, Mathematics Learning.

Received: 2020-07-05

/ Accepted: 2020-09-23

/ Publised: 2020-11-01

\section{Pendahuluan}

Berbagai upaya dilakukan manusia untuk memperoleh ilmu pengetahuan melalui pendidikan (Bunga, Prang, \& Nainggolan, 2015). Sesuai Undang-Undang Nomor 20 Tahun 2003 mengenai sistem pendidikan nasional didefinisikan menjadi suatu yang terencana dan usah sadar dalam mewujudkan kegiatan pembelajaran dan situasi belajar agar siswa mengembangkan potensi secara aktif untuk pribadinya, masyarakat, bangsa dan negara (Dida, Safrudin, \& Mulyani , 2018). Dalam hal ini sekolah sebagai tempat penyelenggara utama, terutama peran dan fungsi guru sebagai fasilitator untuk perkembangan siswa di jalur pendidikan formal, informal, atau nonformal (Pahlevi, Damayani, \& Kiswoyo, 2019).

Pada proses pembelajaran di kelas guru merupakan aspek yang bertanggung jawab dalam menentukan hasil dan kemajuan belajar siswa dengan melakukan evaluasi asumtif saat kenaikan kelas atau akhir semester dan tengah semester, dan menyelesaikan suatu indikator 


\section{AlphaMath \\ Journal of Mathematics Education, 6(2) November 2020}

pencapaian tanpa melihat beberapa aspek lain salah satunya adalah tingkat kemampuan siswa (Oktaviana \& Prihatin, 2018).

Pengambilan keputusan guru untuk menentukan keberhasilan belajar siswa SMK Negeri 1 Maumere yaitu berdasarkan nilai yang diperoleh siswa, guru memberikan soal Latihan dan mengoreksi jawaban siswa untuk memperoleh nilai dan jika siswa mendapatkan nilai sesuai kriteria ketuntasan minimal (KKM) maka siswa dinyatakan sudah menguasai materi pelajaran, tetapi hal tersebut tidak sepenuhnya menjadi penentuan hasil belajar siswa karena tingkat kemampuan siswa tidak sama untuk menyerap materi penjelasan dari guru.

Matematika dan pembelajarannya selalu memperoleh keluhan dan sanggahan dari beberapa bagian, pengamat pendidikan, baik siswa, orang tua, masyarakat, bahkan dari guru sebagai pendidik tentang rendahnya kemampuan siswa dalam menerapkan matematika dalam kehidupan sehari-hari (Warsini, 2019). Matematika didefinisikan sebagai suatu yang telah dilatih dari sekolah dasar sampai tingkat menengah bahkan sampai tingkat perguruan tinggi, maka dari itu dirasa penting seseorang perlu belajar matematika (Mursari, 2019). Pembelajaran matematika di kelas masih dianggap susah dan sulit oleh siswa karena berkaitan dengan angka, kegiatan menghafal, dan lain sebagainya (Shadiq, 2008). siswa mendengar ide-ide tentang matematika merupakan aspek penting dalam pembelajaran berwawasan constructivism (Fadholi, Waluya, \& Mulyono, 2015). Dengan belajar matematika, siswa akan berpikir secara kritis dan kreatif (Wasida \& Hartono, 2018). Matematika adalah kunci dalam memanfaatkan semua peluang (Wahyuddin \& Yusuf).

Hasil belajar adalah suatu tolak ukur untuk melihat berhasilnya siswa dalam memahami materi sesudah melaksanakan kegiatan pembelajaran, dan memperolehnya dengan evaluasi, dan kualitas keberhasilan didapat dari tes pada akhir pembelajaran (Fauziah, 2015). Hasil belajar merupakan sesuatu yang didapatkan melalui pengetahuan, sikap, dan keahlian ditunjukkan dengan nilai (Sutama \& Anggitasari, 2018).

Beberapa tujuan Pendidikan untuk membantu dalam melaksanakan evaluasi hasil belajar adalah taksonomi bloom revisi yang menguraikan enam tingkat respon dalam proses berpikir yaitu aspek pengetahuan $(\mathrm{C} 1)$ merupakan kemampuan mengingat siswa, aspek pemahaman $(\mathrm{C} 2)$ merupakan kemampuan berpikir siswa, aspek aplikasi (C3) kemampuan siswa untuk menyeleksi suatu abstraksi, Aspek analisis (C4) merupakan pemanfaatan kemampuan dari tiga aspek, aspek sintesis (C5) keahlian siswa untuk Menulis lagi masalah, Aspek evaluasi (C6) kemampuan siswa untuk mempertimbangkan suatu keadaan, nilai, dan ide (Amelia, Susanto, \& Fatahillah , 2015).

Dalam proses pembelajaran ada beberapa aspek yang mempengaruhi hasil belajar matematika ialah aspek indivual atau internal yang bersumber dari siswa seperti keadaan jasmani dan rohaninya, aspek sosial atau eksternal siswa yang terjadi dari keadaan lingkungan sekitar siswa seperti keadaan sekolah dan keluarga, sedangkan aspek struktural adalah aspek pendekatan belajar meliputi strategi dan metode digunakan oleh guru dalam kegiatan pembelajaran (Mahmud, 2010). Aspek yang mempengaruhi siswa tersebut menunjukan adanya ragam kepribadian siswa yang turut menentukan hasil belajar di dalam kelas (Yukentin, Munawaroh, \& Winarso, 2018).

Diona Amelia, Susanto, dan Arif Fatahillah menyatakan bahwa hasil belajar matematika siswa sudah amat baik dan telah mencakupi rana kognitif dengan rata-rata persentase peringkat pengetahuan (C1) 92,5\%; pemahaman (C2) 61,2\%, dan aplikasi (C3) 71,2\% (Amelia, Susanto, 
\& Fatahillah , 2015). Selanjutnya Dwi Oktaviana dan Iwit Prihatin menyatakan siswa lebih mampu menyelesaikan soal dengan indikator pemahaman atau understand $60 \%$ dari pada soal dengan indikator menerapkan atau apply 19,2\% dimana siswa dengan kemampuan sudah mencapai indikator memahami maupun menerapkan sedangkan siswa dengan kemampuan rendah tidak mencapai kedua indikator (Oktaviana \& Prihatin, 2018).

Untuk mengetahui pencapaian hasil belajar siswa sesuai proses kognitif guru harus memahami permasalahan yang mempengaruhi siswa dengan menggunakan indikator keberhasilan, sehingga hal tersebut bisa menjadi bahan pertimbangan untuk pencapai hasil belajar yang produktif dalam kegiatan pembelajaran di kelas. Oleh karena itu, perlu untuk menganalisis hasil belajar siswa pada mata pelajaran matematika berdasarkan rana kognitif.

\section{Metode Penelitian}

Metode penelitian ini adalah deskriptif kualitatif dan dilaksanakan di SMK Negeri 1 Mau mere kelas X Jurusan DPIB-2 (Desain Pemodelan dan Informasi Bangunan) dengan subjek yang berjumlah 34 siswa. Instrumen yang digunakan adalah soal tes sebanyak 5 soal dan pertanyaan wawancara tidak berstruktur. Teknik analisis data yang dilakukan adalah deskriptif kualitatif dengan menggunakan data Reduction, data display, Verification dengan hasil yang diperoleh merupakan hasil yang berbentuk skor sesuai dengan aspek-aspek pada indikator sesuai pedoman penskoran yang telah ditentukan maka rumus yang digunakan untuk mendapatkan hasil belajar yaitu:

Keterangan:

$$
P=\frac{f}{n} \times 100 \%
$$

$\mathrm{P}=$ Angka persentase

$\mathrm{F}=$ frekuensi yang dicari persentase nya

$\mathrm{n}$ = banyaknya sampel responden

Dari hasil tes untuk mengetahui pencapaian hasil belajar siswa maka data dianalisis sesuai kriteria hasil belajar dapat diperhatikan pada tabel 1.

Tabel 1. Kriteria Hasil Belajar

\begin{tabular}{|c|c|c|}
\hline $\begin{array}{c}\text { Tingkat } \\
\text { Penguasaan \% }\end{array}$ & Skor Hasil Belajar & Kriteria Hasil Belajar \\
\hline $90-100$ & $90-100$ & Sangat Tinggi \\
\hline $80-89$ & $80-89$ & Tinggi \\
\hline $65-79$ & $65-79$ & Sedang \\
\hline $55-64$ & $55-64$ & Rendah \\
\hline $0-54$ & $0-54$ & Sangat Rendah \\
\hline
\end{tabular}

Sumber: (Mailili, 2018)

\section{Hasil dan Pembahasan}

Untuk memperoleh hasil penelitian dengan empat kali pertemuan adalah hasil tes siswa dalam topik pembahasan perbandingan trigonometri pada segitiga siku-siku dan wawancara siswa bersama guru mata pelajaran. Teknik analisis yang digunakan adalah deskriptif kualitatif dengan melakukan data Reduction, data display, Verification. Berikut adalah hasil analisis data menggunakan deskriptif kualitatif. 


\section{Data Reduction}

Berdasarkan tes yang telah dilaksanakan siswa dalam bentuk soal uraian sesuai indikator hasil belajar, data nilai siswa setelah melaksanakan tes dapat diperhatikan pada tabel 2 berikut.

Tabel 2. Nilai Tes Hasil Belajar Siswa

\begin{tabular}{clcclc}
\hline No & Nama Siswa & Nilai & No & Nama Siswa & Nilai \\
\hline 1 & AHA & 55 & 18 & MFD & 89 \\
2 & APS & 65 & 19 & MMF & 70 \\
3 & AI & 80 & 20 & MNH & 75 \\
4 & BEK & 79 & 21 & MSN & 75 \\
5 & ESD & 55 & 22 & MVD & 80 \\
6 & EFT & 65 & 23 & MRK & 65 \\
7 & EFEP & 79 & 24 & OAP & 90 \\
8 & EF & 70 & 25 & RNM & 79 \\
9 & EPN & 70 & 26 & SMK & 89 \\
10 & FFO & 85 & 27 & SNS & 79 \\
11 & GNEF & 65 & 28 & TOY & 80 \\
12 & HM & 55 & 29 & TAI & 70 \\
13 & JZRD & 65 & 30 & VCB & 80 \\
14 & KN & 75 & 31 & YN & 75 \\
15 & MNS & 55 & 32 & YEL & 65 \\
16 & MIDM & 80 & 33 & YES & 60 \\
17 & MANL & 88 & 34 & YMN & 79 \\
\hline
\end{tabular}

Data pada tabel 2 merupakan nilai tes hasil belajar yang diperoleh siswa, maka dapat dipilih beberapa siswa sesuai kategori hasil belajar untuk melaksanakan wawancara agar peneliti dapat memahami faktor yang mempengaruhi hasil belajar, wawancara ini juga dilakukan pada guru mata pelajaran, jumlah yang menjadi subjek wawancara dapat dilihat pada tabel 3 .

Tabel 3. Jumlah Subjek Untuk Diwawancarai

\begin{tabular}{clc}
\hline No & \multicolumn{1}{c}{ Kategori } & Jumlah siswa \\
\hline 1 & Sangat Tinggi & 1 \\
2 & Tinggi & 3 \\
3 & Sedang & 3 \\
4 & Sangat Rendah & 3 \\
\hline
\end{tabular}

Data pada tabel 3 menampilkan jumlah siswa yang dipilih sebagai subjek wawancara sesuai kategori hasil belajar.

\section{Data Display}

Berdasarkan nilai tes hasil belajar siswa maka berikutnya pembagian jumlah hasil belajar siswa menurut kriteria, data pembagian nilai sesuai kategori dapat diperhatikan tabel 4.

Data pada tabel 4 merupakan penyajian hasil pembagian nilai siswa sesuai kriteria hasil belajar, maka dapat dihitung frekuensi persentase nilai tes hasil belajar siswa sesuai kriteria hasil belajar, data frekuensi persentase nilai sesuai kriteria hasil belajar dapat diperhatikan pada tabel 5 . 
Tabel 4. Pembagian Nilai Sesuai Kriteria Hasil Belajar Siswa

\begin{tabular}{ccc}
\hline Kriteria & Nilai Siswa & Jumlah Siswa \\
\hline Sangat Tinggi & 90 & 1 \\
Tinggi & 85 & 1 \\
& 88 & 1 \\
Sedang & 89 & 2 \\
& 75 & 4 \\
& 79 & 4 \\
Rendah & 80 & 5 \\
& 85 & 5 \\
Sangat Rendah & 55 & 4 \\
& 60 & 1 \\
\hline
\end{tabular}

Tabel 5. Frekuensi Nilai Siswa

\begin{tabular}{ccc}
\hline Skor & Frekuensi & $\begin{array}{c}\text { Persentase } \\
\%\end{array}$ \\
\hline $90-100$ & 1 & 2,9 \\
$80-89$ & 9 & 26,5 \\
$65-79$ & 19 & 55,9 \\
$55-64$ & 5 & 14,7 \\
$0-54$ & 0 & 0 \\
Jumlah & 34 & 100 \\
\hline
\end{tabular}

Data pada tabel 5 merupakan penyajian frekuensi persentase nilai hasil belajar matematika. Kemudian siswa diwawancara sesuai kriteria dan dapat dihitung frekuensi persentase hasil wawancara, data frekuensi persentase wawancara bisa diperhatikan tabel berikut.

Tabel 6. Frekuensi Wawancara Siswa

\begin{tabular}{lccc}
\hline \multirow{2}{*}{ Pertanyaan } & \multicolumn{2}{c}{ Frekuensi } & Persentase \\
\cline { 2 - 3 } & Ya & Tidak & $\%$ \\
\hline Menyukai mata pelajaran & & 6 & 60 \\
matematika. & 4 & & 40 \\
Kesulitan belajar matematika. & 9 & & 90 \\
& & 1 & 10 \\
Mengulang materi di rumah. & & 6 & 60 \\
Kepuasan dengan hasil tes. & 4 & & 40 \\
& 4 & & 40 \\
Memahami materi penjelasan & & 6 & 60 \\
& & 3 & 30 \\
& 7 & & 70 \\
\hline
\end{tabular}

Data pada tabel 6 merupakan penyajian frekuensi persentase wawancara siswa sesuai kriteria hasil belajar. Setelah mengetahui hasil wawancara siswa maka dilakukan wawancara terhadap guru, guru berpendapat bahwa model yang di gunakan saat melaksanakan pembelajaran di kelas adalah discover learning, mengenai kondisi siswa kemampuan dasar berhitung nya siswa kurang, konséntrasi kurang, dan ada beberapa siswa yang kurang aktif. 
Verification

Persentase hasil belajar siswa pada mata pelajaran matematika kelas X DPIB-2 dilihat pada gambar 1.

\section{Hasil Belajar Siswa Pada Mata Pelajaran Matematika Kelas X DPIB-2}
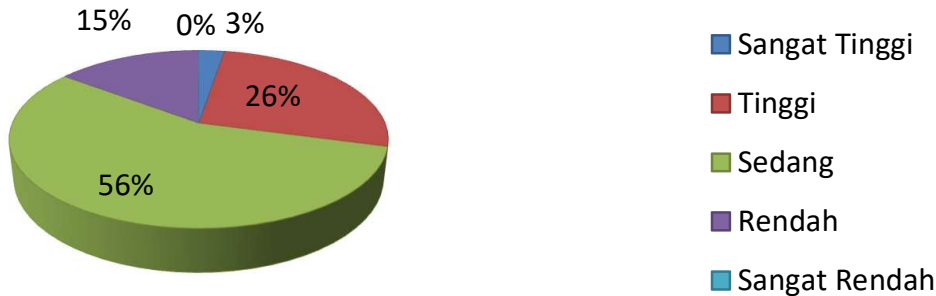

Gambar 1: Persentase Hasil Belajar Matematika Siswa Kelas X DPIB-2 di SMK Negeri 1 Maumere

Pada gambar 1 merupakan penyajian persentase hasil belajar matematika siswa setelah melaksanakan pembelajaran di kelas. Berikut hasil persentase wawancara siswa sesuai kriteria hasil belajar dapat dilihat pada gambar 2.

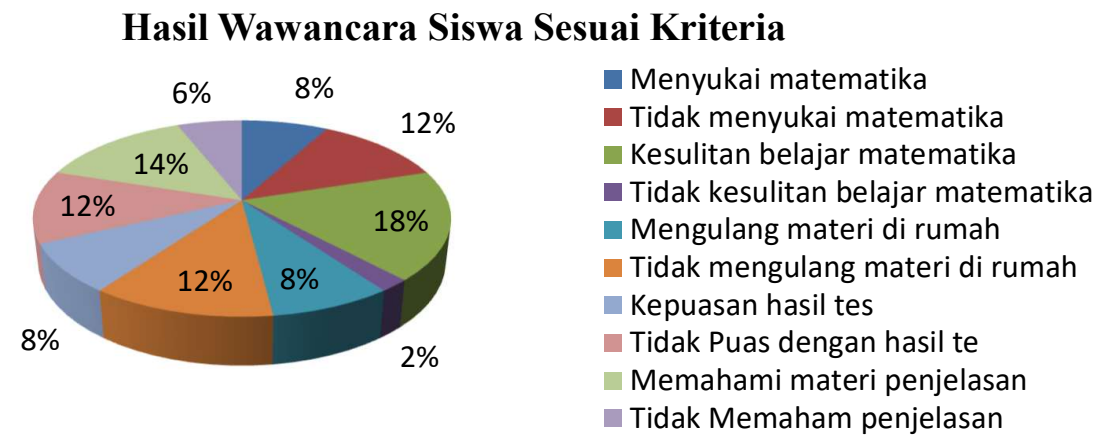

Gambar 2: Persentase Hasil Wawancara Siswa Kelas X DPIB-2 di SMK Negeri 1 Maumere Sesuai Kriteria Hasil Belajar

Pada gambar 2 merupakan penyajian persentase wawancara siswa sesuai kriteria hasil belajar setelah melakukan wawancara dari beberapa siswa. Analisis data dilakukan dengan cara menganalisis dan mengolah data menggunakan sistem perhitungan statistik, sesuai hasil analisis data yang diperoleh menurut kriteria hasil belajar pada siswa dengan kriteria rendah jumlahnya cukup, kriteria sedang jumlahnya sangat banyak, kriteria tinggi jumlahnya banyak, kriteria sangat tinggi jumlahnya kurang.

Berdasarkan penelitian sebelumnya yang dilakukan oleh Amelia dkk. menyatakan bahwa hasil belajar matematika siswa sudah amat baik dan telah mencakupi rana kognitif, sedangkan dari hasil penelitian ditemukan di lapangan dan sesuai perhitungan data yang diperoleh, peneliti menyatakan bahwa hasil belajar siswa kelas X DPIB-2 di SMK Negeri 1 Maumere mencapai kriteria baik.

Setelah mengetahui kemampuan hasil belajar siswa peneliti melakukan wawancara untuk mendapatkan aspek yang mempengaruhi hasil belajar siswa, menurut Yukentin (2018). 
mengatakan aspek yang mempengaruhi hasil belajar siswa diantar nya aspek internal seperti kondisi jasmani atau rohani siswa, aspek eksternal seperti lingkungan sekolah dan keluarga, dan aspek struktural seperti pendekatan atau model pembelajaran digunakan saat pembelajaran di kelas, dari hasil wawancara siswa peneliti mendapatkan aspek yang sering mempengaruhi hasil belajar siswa kelas X DPIB-2 di SMK Negeri 1 Maumere adalah aspek internal meliputi Siswa mempunyai keinginan belajarnya kurang, kemampuan pemahaman pada materi kurang, daya ingat pada materi kurang, kurangnya keahlian berhitung dan aspek eksternal meliputi kurangnya perhatian dan dukungan keluarga terhadap siswa untuk mengulangi materi yang diberikan oleh guru di rumah, sedangkan pada aspek struktural tidak mempengaruhi selama pelaksanaan pembelajaran di kelas.

\section{Simpulan}

Sesuai penelitian dengan hasil pengolahan data dan pembahasan, siswa dengan kriteria rendah jumlahnya cukup, kriteria sedang jumlahnya sangat banyak, kriteria tinggi jumlahnya banyak, kriteria sangat tinggi jumlahnya kurang, maka peneliti menyimpulkan bahwa hasil belajar pada siswa kelas X DPIB-2 di SMK Negeri 1 Maumere mencapai kriteria baik, sedangkan aspek yang mempengaruhi hasil belajar matematika siswa adalah aspek Internal meliputi siswa mempunyai minat belajarnya kurang, Kemampuan pemahaman pada materi kurang, daya ingat pada materi kurang, Kurangnya keahlian berhitung dan aspek eksternal meliputi kurangnya perhatian dan dukungan keluarga terhadap siswa untuk mengulangi materi diberikan oleh guru di rumah.

\section{Daftar Pustaka}

Amelia, D., Susanto, \& Fatahillah, A. (2015). Analisis Hasil Belajar Matematika Siswa Pada Pokok Bahasan Himpunan Berdasarkan Ranah Kognitif Taksonomi Bloom Kelas ViiA Di Smpn 14 Jember. Edukasi Unej, Ii(1), 1-4.

Bunga, N. K., Prang, J., \& Nainggolan, N. (2015). Hubungan Antara Minat Belajar Dan Hasil Belajar Matematika Siswa Sma Kristen Eben Haezer Ibu Dengan Menggunakan Analisis Regresi. $J d c, 4(2), 1-5$.

Dida, M. Y., Safrudin, N., \& Mulyani , S. (2018). Pengaruh Penggunaan Model Pembelajaran Kooperatif Tipe Think Pair Share Terhadap Hasil Belajar Matematika Siswa Kelas Xi Smk Negeri 1 Talibura, Ikip Muhammadiyah Maumere. Birunimatika, 3(2), 1-4.

Fadholi, T., Waluya, B., \& Mulyono. (2015). Analisis Pembelajaran Matematika Dan Kemampuan Literasi Serta Karakter Siswa Smk. Unnes Journal Of Mathematics Education Research, 4(1), 1-7.

Fauziah. (2015). Meningkatkan Hasil Belajar Matematika Siswa Kelas Xi Ips Sma Tamansiswa Padang Dengan Penggunaan Pendekatan Kontekstual Berbasis Tugas Yang Menantang (Challenging Task). Lemma, I(2), 1-10.

Mahmud. (2010). Psikologi Pendidikan. Bandung : Pustaka Setia,372-376.

Mailili, W. H. (2018). Deskripsi Hasil Belajar Matematika Siswa Gaya Kognitif Field Independent Dan Field Dependent. Anargya: Jurnal Ilmiah Pendidikan Matematika, $1(1), 1-7$.

Mursari, C. (2019). Deskripsi Kemampuan Berikir Kritis Matematis Dan Kemandirian Belajar Siswa Ditinjau Dari Gaya Belajar. Alphamath (Journal Of Mathematics Education), $5(2), 40-48$. 
Oktaviana, D., \& Prihatin, I. (2018). Analisis Hasil Belajar Siswa Pada Materi Perbandingan Berdasarkan Ranah Kognitif Revisi Taksonomi Bloom, Ikip Pgri. Buana Matematika: Jurnal Ilmiah Matematika Dan Pendidikan Matematika, 8(2), 1-8.

Pahlevi, A., Damayani, A. T., \& Kiswoyo. (2019). Keefektifan Model Nht (Numbered Heads Together) Berbantu Media Sapuan Terhadap Hasil Belajar Matematika. International Journal Of Elementary Education., 3(1), 9-15.

Sutama, \& Anggitasari, B. (2018). Gaya Dan Hasil Belajar Matematika Pada Siswa Smk. Jurnal Managemen Pendidikan , 13(1), 1-10.

Wahyuddin, \& Yusuf, I. W. (N.D.). Efektivitas Pembelajaran Matematika Melalui Penerapan Model Kooperatif Tipe Student. Jurnal Pendidikan Matematika Indonesia, 5(1), 16 23.

Warsini, T. (2019). Penerapan Model Tai Untuk Meningkatkan Kemampuan Kerjasama Dan Hasil Belajar Matematika Materi Barisan Dan Deret Kelas Ixc Smp Negeri 4 Sumbang Semester 2 Tahun Pelajaran 2. Alphamath (Journal Of Mathematics Education),, 5(2), $9-14$.

Wasida, M. R., \& Hartono, H. (2018). Jurnal Riset Pendidikan Matematika. Analisis Kesulitan Menyelesaikan Soal Model Ujian Nasional Matematika Dan Self-Efficacy Siswa Sma, 5(1), 82-95.

Yukentin, Y., Munawaroh, M., \& Winarso, W. (2018). Analisis Hasil Belajar Matematika Siswa Ditinjau Dari Perbedaan Kepribadian Ekstrovert Dan Introvert. Jurnal Ilmiah Pendidikan Matematika, 3(2), 163-168. 